\title{
Insulating Polymer Coated Si Photoelectrode
}

\author{
Soichiro YAMAMURA and Wasaburo KAWAI \\ Government Industrial Research Institute, Osaka, \\ 8-31, Midorigaoka 1-chome, Ikeda 563, Japan
}

(Received June 21, 1984)

\begin{abstract}
KEY WORDS Silicon / Polymer Film / Photovoltaic Cell / Photoelectrochemical Cell / Stabilization /
\end{abstract}

Recently many chemists have called attention to hybridization of a semiconductor electrode with polymer in a photocell. One may gain several advantages, including improvement of the efficiency of energy conversion ${ }^{1-3}$ and of the stability against photocorrosion. ${ }^{4-8}$ Minami and co-workers reported the utilization of poly(vinylidene fluoride) as a binder and it's polarity improved the conversion efficiency in a particular phthalocyanine photovoltaic cell. ${ }^{3}$ Skotheim and Lundström used polypyrrole films to obtain the stabilization of $n$-Si in a photovoltaic cell. ${ }^{7} \mathrm{We}$ also constructed various types of hybrid electrodes, involving semiconductor electrodes with hydrophilic photosensitized membranes, and gained remarkable improvement in photoelectrochemical properties of such hybrid electrodes..$^{9-12}$ Here we report a new type of Si-photoelectrode coated with a commodity polymer, poly(vinyl butyral) (PVB), which has been widely used as an insulating film and has an excellent adhesion property to metal. First, this polymer coating has been applied to $n-\mathrm{Si}$ and $p-\mathrm{Si}$ photovoltaic cells to show the formation of Schottky junction. Second, the polymer coated $n$-Si electrode has been applied to a photoelectrochemical cell to examine the stability against photocorrosion. We have shown that the electrodes of this type have wide applications owing to simple fabrication as well as good characteristics in the stability and the conversion efficiency.

A typical construction of the photovoltaic cell is shown in Figure 1. An adherent plate of nickle was deposited on an $n$-Si (resistivity, $4 \sim 6 \Omega \mathrm{cm}$; area, $1 \mathrm{~cm}^{2}$ ) wafer in order to make an ohmic contact. ${ }^{13}$ The $n$-Si was then connected with a $\mathrm{Cu}$ wire by $\mathrm{Ag}$ paste. A solution of $6.7 \%$ PVB in $N, N$-dimethylformamide (DMF) was cast on the $n$-Si electrode. The polymer was purchased from Wako Junyaku and the degree of polymerization was ca. 700. Nesa glass of $\mathrm{SnO}_{2}(0.7 \mathrm{k} \Omega \mathrm{cm})$ or $\mathrm{In}_{2} \mathrm{O}_{3}(15 \Omega \mathrm{cm})$ was used as a counter electrode. Then DMF was evaporated at $50^{\circ} \mathrm{C}$ and at $5 \times 10^{-14} \mathrm{mmHg}$ for several hours. The thickness of the film was measured with a tally step instrument (Kosaka Laboratory). It was $c a$. $800 \AA$. The photovoltaic cell was illuminated from the Nesa side with a $500 \mathrm{~W}$ xenon lamp. The light of a shorter wavelength was cut at $380 \mathrm{~nm}$ by a glass filter (Hoya L-380).

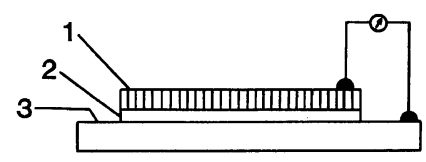

Figure 1. The construction of the photovoltaic cell: 1, $n$-Si; 2, polymer film; 3 , Nesa glass. The cell is illuminated from the Nesa glass side with a $500 \mathrm{~W}$ Xe lamp $(>380 \mathrm{~nm})$. 


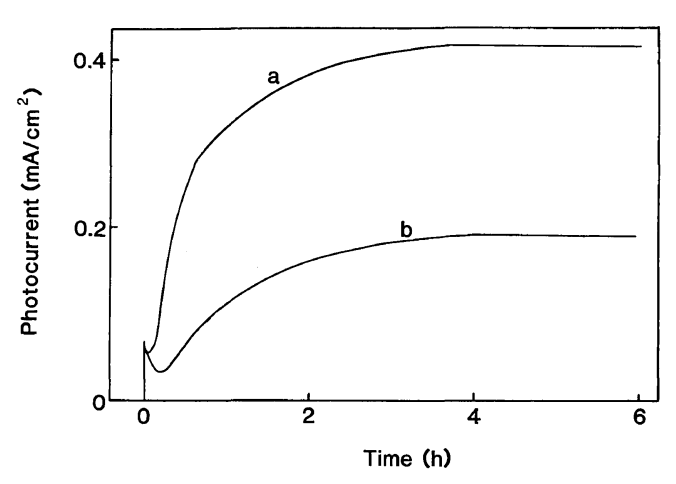

Figure 2. Short circuit photocurrent vs. time curves of the $n$-Si/polymer film/Nesa photovoltaic cell: a, with $\mathrm{In}_{2} \mathrm{O}_{3}$; b, with $\mathrm{SnO}_{2}$.

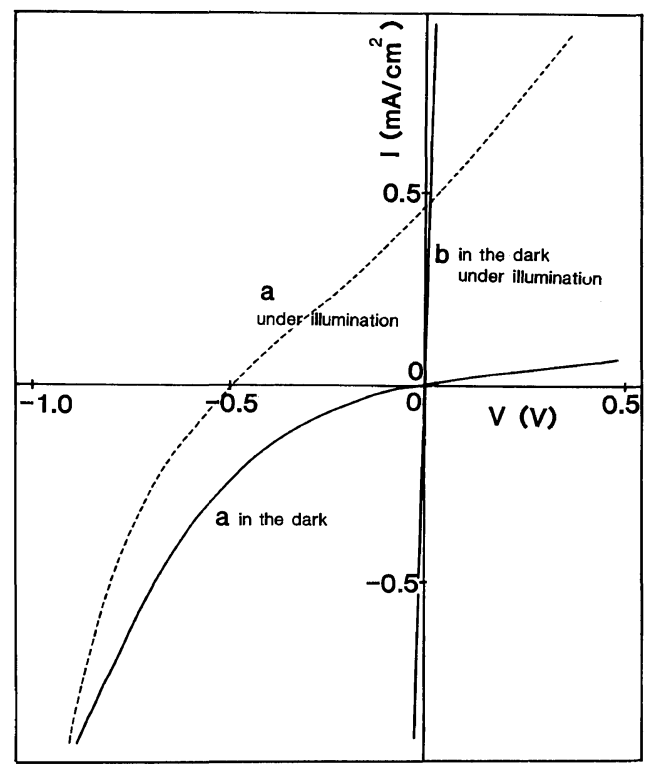

Figure 3. $\mathrm{I}-\mathrm{V}$ characteristics of the photovoltaic cell: a, $n$-Si/polymer film $/ \mathrm{In}_{2} \mathrm{O}_{3}$; b, $n$-Si/ $\mathrm{In}_{2} \mathrm{O}_{3}$ (without polymer). The broken and the solid lines indicate a condition with and without the illumination, respectively. In the case of $b$, the illumination makes no difference. The scan rate is $100 \mathrm{mV} \mathrm{s}^{-1}$ in the case of a and $1 \mathrm{mV} \mathrm{s}^{-1}$ in the case of $b$.

Figure 2 shows the short circuit photocurrent $v s$. time curves for the photovoltaic cell of the configuration of $n$-Si/polymer film/Nesa. The photocurrent rose gradually and reached a steady state.

Figure 3 shows $\mathrm{I}-\mathrm{V}$ characteristics of the $n$ -
$\mathrm{Si} / \mathrm{In}_{2} \mathrm{O}_{3}$ photovoltaic cells with the polymer film and without the polymer film. It is clear that a Schottky contact is observed with the polymer film (line a), while an ohmic contact is observed without the polymer film (line b). Without the polymer film, the short circuit photocurrent was only $0.6 \mu \mathrm{A}$ and the open circuit photocurrent was $0.11 \mathrm{mV}$. They were much smaller than the values observed using the polymer film. There may be pin holes in the polymer film, but this result denies that the photocurrent flows through pin holes. In a semiconductor Schottky barrier diode, there is a region in which the forward current $(I)$ in a small range of applied voltage $(V)$ varies as $\exp (q V / n k T)$, where $n$ is a quality factor and $q$ is the charge of electron. Therefore, in the forward direction where the $n$-Si side is negatively biased, there is a linear relation between $\ln I$ and $V$. The $n$ value was 4.5 although $n$ should be 1 in an ideal junction. This may be interpreted in terms of that the insulating property of the polymer film causes the $n$ value to increase. There may be many electron trapping levels in this insulating film. Electrons may move in the film by the mechanism of tunneling through these levels. The holes generated on the $n$-Si surface under photoirradiation thus combine with electrons.

This polymer coating method has been applied to a $p$-Si (resistivity, $10 \sim 20 \Omega \mathrm{cm}$; area, $1 \mathrm{~cm}^{2}$ ) electrode. The photovoltaic cell using $p$ $\mathrm{Si}$ was fabricated in a manner similar to that described above. Figure 4 shows the short circuit photocurrent $v s$. time curves for the photovoltaic cell of the configuration of $p$ $\mathrm{Si} /$ polymer film/Nesa. Remarkable features of this photovoltaic cell were fast photoresponse and excellent stability. The open circuit photovoltages were $225 \mathrm{mV}$ with the $\mathrm{SnO}_{2}$ electrode and $250 \mathrm{mV}$ with the $\mathrm{In}_{2} \mathrm{O}_{3}$ electrode. They are contrasted with those of $n$-Si electrode, where the open circuit photovoltages were $130 \mathrm{mV}$ with the $\mathrm{SnO}_{2}$ electrode and $55 \mathrm{mV}$ with $\mathrm{In}_{2} \mathrm{O}_{3}$, respectively. Without the polymer film, the short circuit photocurrent 


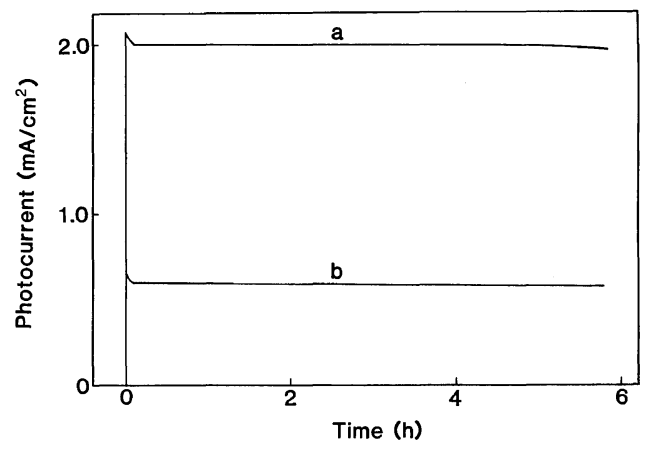

Figure 4. Short circuit photocurrent vs. time curves of the $p$-Si/polymer film/Nesa photovoltaic cell: a, with $\mathrm{In}_{2} \mathrm{O}_{3}$; b, with $\mathrm{SnO}_{2}$.

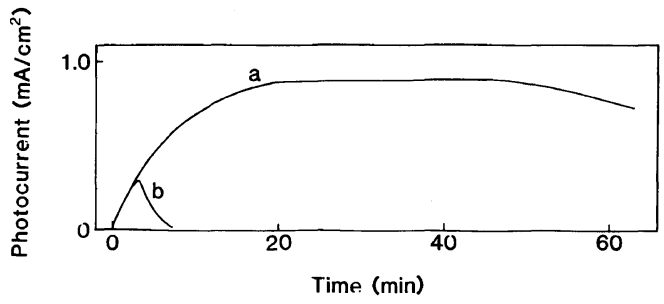

Figure 5. Short circuit photocurrent $v s$. time curves of the photoelectrochemical cell: a, polymer coated $n-\mathrm{Si}$ / redox solution $/ \mathrm{Pt} ; \mathrm{b}$, bare $n-\mathrm{Si} /$ redox solution $/ \mathrm{Pt}$. The redox solution composes of $0.5 \mathrm{M} \mathrm{FeSO}, 0.15 \mathrm{M}$ $\mathrm{Fe}_{2}\left(\mathrm{SO}_{4}\right)_{3}$, and $0.5 \mathrm{M} \mathrm{H}_{2} \mathrm{SO}_{4}$ in $\mathrm{H}_{2} \mathrm{O}$.

was $6.8 \mu \mathrm{A}$ and the open circuit photovoltage was $5 \mathrm{mV}$ with the $\operatorname{In}_{2} \mathrm{O}_{3}$ electrode. It should be emphasized that a $p$-Si electrode shows a better characteristics in efficiency and stability than an $n$-Si electrode by the coating.

Figure 5 shows the effect of the polymer film on a photocorrosion of an $n$-Si electrode in a photoelectrochemical cell. The cell configuration was $n$-Si/polymer film/redox solution/ $\mathrm{Pt}$. The redox solution consists of $0.5 \mathrm{M} \mathrm{FeSO}_{4}$ and $0.15 \mathrm{M} \mathrm{Fe}_{2}\left(\mathrm{SO}_{4}\right)_{3}$ in $0.5 \mathrm{M} \mathrm{H}_{2} \mathrm{SO}_{4}$. In the figure the curves of the short circuit photocurrent $v s$. time are compared between a bare $n$-Si electrode and the polymer coated $n$-Si electrode. It is noted that the polymer coating remarkably improves the stability against photocorrosion. It mainly owes to hydrophobicity of the polymer. The decrease of the photocurrent is attributed to the penetration of $\mathrm{H}_{2} \mathrm{O}$ molecules into the $n$-Si surface.

The detailed study on the band structure at the semiconductor/polymer junction and the mechanism of the electrical conduction are now in progress.

\section{REFERENCES}

1. R. O. Loufty, J. H. Sharp, C. K. Hsiano, and R. Ho, J. Appl. Phys., 52, 5211 (1981).

2. Z. D. Popovic, J. Chem. Phys., 76, 2714 (1982).

3. N. Minami, K. Sasaki, and K. Tsuda, J. Appl. Phys., 54, 6764 (1983).

4. R. Nouf, A. S. Frank, and A. J. Nozic, J. Am. Chem. Soc., 103, 1849 (1981).

5. T. Skotheim, I. Lundström, and J. Prejza, $J$. Electrochem. Soc., 128, 1625 (1981).

6. T. Skotheim, I. Lundström, A. E. Delahoy, F. J. Kampus, and P. E. Vanier, Appl. Phys. Lett., 40, 281 (1982).

7. T. Skotheim and I. Lundström, J. Electrochem. Soc., 129, 894 (1982).

8. O. Inganäs, T. Skotheim, and I. Lundström, J. Appl. Phys., 54, 3636 (1983).

9. W. Kawai and S. Yamamura, J. Chem. Soc. Jpn., 8, 1217 (1981).

10. S. Yamamura and W. Kawai, J. Chem. Soc. Jpn., 8, 1287 (1982).

11. W. Kawai and S. Yamamura, J. Membrane Sci., 12, 107 (1982).

12. S. Yamamura and W. Kawai, Kobunshi Ronbunshu, 40, 109 (1983).

13. M. V. Sullivan and J. H. Eigler, J. Electrochem. Soc., 104, 226 (1957). 